\title{
FLUOTHANE IN OBSTETRICAL ANAESTHESIA ${ }^{1}$
}

\author{
Prepared by \\ C. A. Sherman, M.D., and J. G. Robson, F.F.A R C.s.(Eng.)
}

FOR A NEW ANAESTHETIC agent to be acceptable it has to offer some significant advantage over agents which are in current use. There is at present no ideal anaesthetic for obstetrical use and some compromise always has to be made between the needs of the mother and child and those of the obstetrician. The present authors (1) reported on a series of 233 obstetrical deliveries using Fluothane, and stated that "it would appear that it [Fluothane] will eventually become establıshed in most obstetric units because it fulfils a long felt need as a substitute for chloroform." Since then three papers $(2,3,4)$ have appeared on the use of the drug in obstetrical anaesthesıa and indicate that, while satisfactory anaesthesia can be obtained, undue uterine relaxation is a major disadvantage. These authors advise against its use in this field, with the exception of Dixon and Matheson (4) who add in a footnote that this is being reconsidered.

The present paper presents a series of Fluothane anaesthetics administered over the years 1956 to 1959 in the Department of Obstetucs of the Royal Victoria Hospital, Montreal, and an attempt is made to answer the question, "Does Fluothane have anythung to offer the mother, child, or obsterician as an advantage over the anaesthetics in current use?"

It is felt that to make the results intelligible the type of obstetrical practice in the Royal Victoria Hospital should be noted. The Department manages a yearly average of 3,239 confinements (1948-1957) Of these, approximately half are delivered in two private case-rooms and half in two public case-rooms The private rooms are served drectly by 12 staff anaesthetists on a 24-hour rotational basis, the public ones by 12 resident anaesthetists on a similar basis with staff supervision In general, in Montreal, most confinements take place in hospital so that a large part of the practice is normal obstetrics. In 1957, for example, the Caesarean section rate was 35 per cent breech deliveries amounted to 34 per cent, and the high forceps rate was 012 per cent A five-year survey of forceps deliveries is given in Table I. The foetal and maternal mortality

TABLE I

Five-year Survey of Forceps Deliveries in the Royal Victoria Hospital, MONTREal

\begin{tabular}{|c|c|c|c|c|c|}
\hline \multirow{2}{*}{ Year } & \multicolumn{2}{|c|}{ Low-forceps } & \multicolumn{2}{|c|}{ Mid-forceps } & \multirow{2}{*}{$\begin{array}{c}\text { Total } \\
\text { confinements }\end{array}$} \\
\hline & No & $\%$ & No & $\%$ & \\
\hline 1953 & 1,267 & 381 & 193 & 58 & 3,317 \\
\hline 1954 & 1,188 & 344 & 238 & 69 & 3,451 \\
\hline 1955 & 976 & 291 & 192 & 57 & 3,348 \\
\hline 1956 & 898 & 276 & 145 & 45 & 3,253 \\
\hline 1957 & 842 & 250 & 170 & 50 & 3,378 \\
\hline
\end{tabular}

${ }^{1}$ A report from the Department of Anaesthesıa of the Royal Victor 1 Hospital, Montreal, P.Q. 
TABLE II

Foetal and Maternal Mortality for 1956

\begin{tabular}{lcccc}
\hline \hline & Canada & Quebec U S A & R V H \\
\hline $\begin{array}{l}\text { Foetal mortality } \\
\text { (per 1,000 live births) }\end{array}$ & 35 & 44 & & 24 \\
$\begin{array}{l}\text { Maternal mortality } \\
\text { (per 10,000 live births) }\end{array}$ & 6 & 9 & 4 & 5 \\
\hline
\end{tabular}

TABLE III

DISTRIBUTION OF ANAESTHETICS FOR Vaginal Deliveries, 1957 and 1958

\begin{tabular}{|c|c|c|c|c|}
\hline & \multicolumn{2}{|c|}{1957} & \multicolumn{2}{|c|}{1258} \\
\hline & Total & $\%$ & Total & $\%$ \\
\hline $\begin{array}{l}\text { Nitrous oxide } \\
\text { trilene } \\
\text { Nitrous oxide }\end{array}$ & 1,418 & 5490 & 1,553 & $\begin{array}{lll}60 & 10\end{array}$ \\
\hline $\begin{array}{l}\text { fluothane } \\
\text { Cyclopropane } \\
\text { Nitrous oxide } \\
\text { Spinal } \\
\text { Epidural } \\
\text { ToTAL }\end{array}$ & $\begin{array}{c}713 \\
83 \\
163 \\
175 \\
31 \\
2,583\end{array}$ & $\begin{array}{rl}27 & 60 \\
3 & 21 \\
6 & 31 \\
6 & 78 \\
1 & 20 \\
100 & 00\end{array}$ & $\begin{array}{r}631 \\
67 \\
186 \\
104 \\
43 \\
2,584\end{array}$ & $\begin{array}{rl}24 & 03 \\
2 & 59 \\
7 & 20 \\
4 & 02 \\
1 & 66 \\
100 & 00\end{array}$ \\
\hline
\end{tabular}

figures for the hospital compared to the federal and provincial figures are given in Table II.

Table III shows the numbers and types of anaesthetics used in 1957 and 1958 for vaginal deliveries No anaesthetist was present in about 20 per cent of the cases. Spinal anaesthesia is declinıng in popularity for vaginal delivery and only 104 were given in 1958 as compared with 1,125 in 1951 although this latter figure includes those given for Caeserean section. As a rule epidural analgesia is used for delivery only when it is induced durng the course of labour for pain relief.

It is possible to divide the general anaesthesı into four main categories Furst, nitrous oxide and oxygen are given intermittently for the termination of the second stage of labour and the crowning of the head. Secondly, where episiotomy has to be performed, slightly deeper anaesthesia has to be obtained for the incision and analgesia is maintained thereafter. In both of these categories light surgical anaesthesia is induced for the repaur of the perineum. Thirdly, for operatıve delivery, anaesthesia is required which is just deep enough to prevent reflex movement with manıpulation and, after delivery, is lightened during repair of the perineum. Fourthly, relatively deep anaesthesia is required for intrauterine manipulation.

The tendency is to avoid the use of general anaesthessia when labour has been prolonged or difficult, or when a meal has been takem. Patients for general anaesthesia are all given atropine sulphate $0.4 \mathrm{mg}$. int:amuscularly or intravenously before anaesthesia. Sedative premedication is not used deliberately, but frequently $50 \mathrm{mg}$. or $100 \mathrm{mg}$. of meperidine with $0.2 \mathrm{mg}$. to $0.4 \mathrm{mg}$ hyoscine are given within the preceding 4 hours. In this series Fluothane was used to 


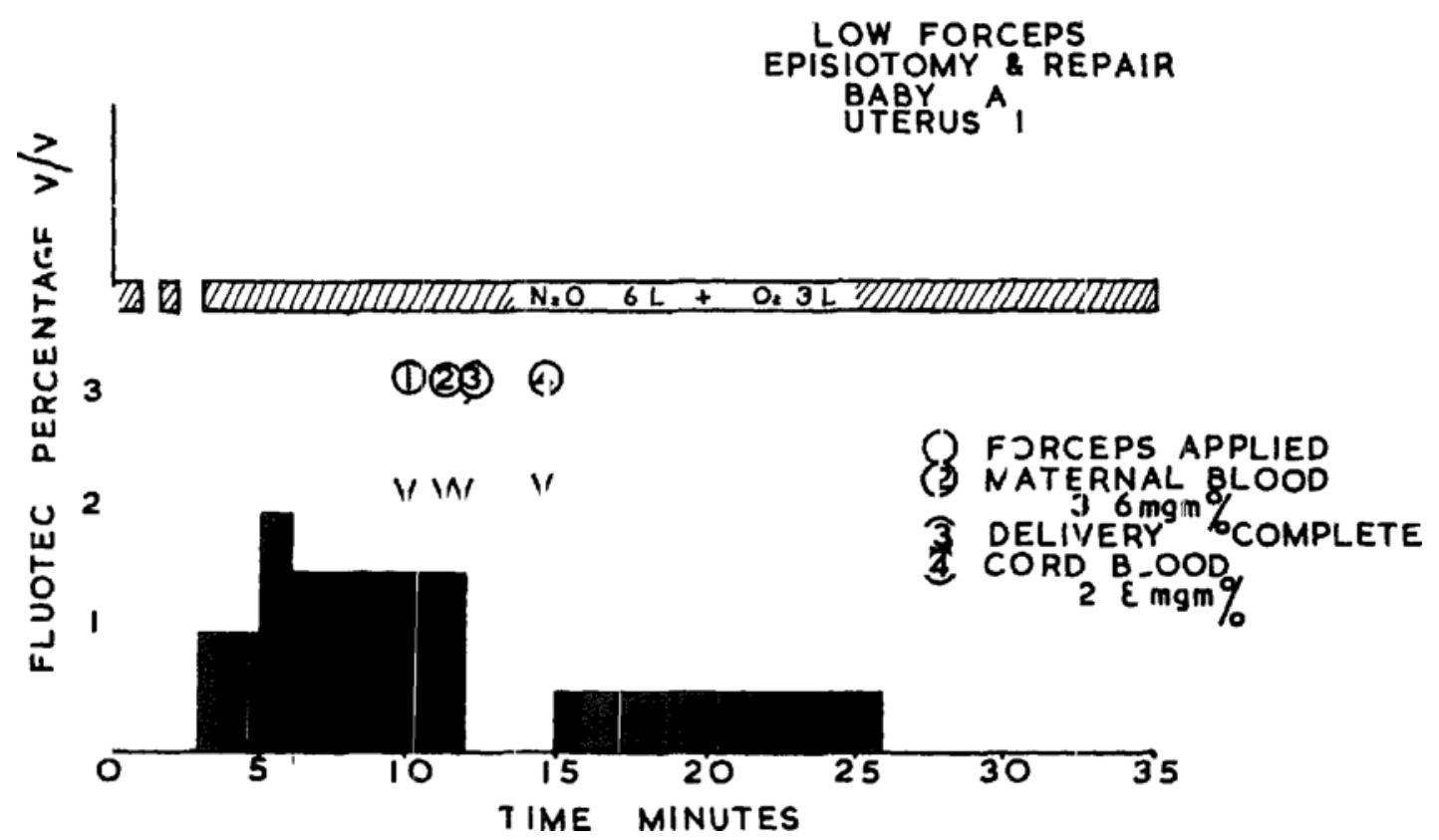

Figure 1 Typical low-forceps delivery anaesthetic chart.

supplement nitrous oxıde and oxygen anaesthesia in 1,601 instances. A Boyle's type anaesthetic machine with the Magill attachment was used for the administration of Fluothane in the majority of patients, the liquid being placed in the ether bottle. A Fluotec vaporizer was used in conjunction with this machine in the last hundred cases Gas flow rates of 6 or $7 \mathrm{I}$ of nitrous oxide and 2 or $3 \mathrm{l}$. of oxygen per minute were used. Maximum Fluothane concentrations used varied between 2 and 3 per cent by volume of the mixture, this being reached within a few breaths As soon as the patient was tranquil, the concentration was reduced and Fluothane was discontinued as soon as the baby was delivered. In the typical case the induction to delivery time was 5 or 6 minutes. When the cord was clamped the nitrous oxide/oxygen ratio was increased to $7 / 2$ to take full advantage of this agent and Fluothane was added intermittently to subdue responses. This most usually consisted of giving 1 or 2 per cent of vapour for 1 or 2 minutes. The duration and depth of anaesthesia were varied to meet obstetrical requirements. Figures 1 and 2 show typical administrations The principle has been to use the minimum concentration of Fluothane for the minimum length of time.

Babies were classified into four categories.

A. Infant breathes and cies within 1 minute and continues to do so as a normal infant should

B. Condition good but not excellent, recovers within 5 minutes to Class A standard

C Condition fair to poor with moderate anoxia, gas jing respiration, and blue congested skm; responds to active resuscitation reac.ung good condition within 30 minutes

D. Condition serıous with severe anoxia and collapse; respiration absent, skin pale and clammy, muscle tone absent, heart beat feeble and irregular, responds only slowly to actıve resuscitation and condition still not good after 30 minutes

E. Stillborn 




Figure 2 Typical spontaneous delivery with episiotopy and repair anaesthetic chart

We have been unable to trace the author of this scoung system Class $A$ corresponds farrly closely to the Apgar ratings 8,9 , and 10; Class B corresponds to ratings 5, 6, and 7, Class $C$ to 3 and 4 , Class $D$ to 0,1 , and 2 .

Uterine tone was assessed as falling into one of three classes. (i) normal uterine tone in the third stage, (u) other than Class I or Class 3; (iii) frank postpartum haemorrhage (over $500 \mathrm{cc}$. blood loss).

The concentration of Fluothane in the blood was estimated by the modified method of Duncan (5). Blood from the mother was taken at the moment of delivery, the veins of the back of the warmed hand being used. The concentrations given for the babies are those obtained in the blood of a segment of cord obtained from the obstetrician as soon as was practicable after delivery.

\section{REsULTS}

Table IV shows the ratungs for the babies, the first part for the whole series of Fluothane anaesthetics, the second part for Fluothane anaesthetics given in 1958, and, for comparison, the ratings for babies born when all other types of anaesthetics were used including spinal and epidural analgesia in 1958. In the whole group of Fluothane anaesthetics the figure of 10.18 per cent for babies rated as $B$ is greater than the figure of 8.53 per cent for the same rating in the control group. This difference is probably significant (chi-square: 5 per cent level). When the 1958 Fluothane ratings are compared to the control group there are no significant differences. 
TABLE IV

SCORING FOR BABIES

\begin{tabular}{|c|c|c|c|c|c|c|}
\hline & \multicolumn{2}{|c|}{$\begin{array}{l}\mathrm{N}_{2} 0+\text { Fluothane } \\
\text { Nov } 1956-\text {-Feb } 1959\end{array}$} & \multicolumn{2}{|c|}{$\begin{array}{c}\mathrm{N}_{2} \mathrm{O}+\text { Fluothane } \\
1958\end{array}$} & \multicolumn{2}{|c|}{$\begin{array}{l}\text { All other anaesthetics } \\
1958 \text { (Control) }\end{array}$} \\
\hline & No & $\%$ & No & $\%$ & No & $\%$ \\
\hline $\begin{array}{c}\mathrm{A} \\
\mathrm{B} \\
\mathrm{C} \\
\mathrm{D} \\
\mathrm{E} \\
\text { TOTAL }\end{array}$ & $\begin{array}{r}1,396 \\
163 \\
22 \\
5 \\
15 \\
1,601\end{array}$ & $\begin{array}{rl}87 & 21 \\
10 & 18^{*} \\
1 & 37 \\
0 & 31 \\
0 & 93\end{array}$ & $\begin{array}{r}491 \\
59 \\
11 \\
0 \\
5 \\
566\end{array}$ & $\begin{array}{rr}86 & 75 \\
10 & 43 \\
1 & 94 \\
0 & 88\end{array}$ & $\begin{array}{r}1,729 \\
166 \\
23 \\
3 \\
26 \\
1,947\end{array}$ & $\begin{array}{rr}88 & 80 \\
8 & 53 \\
1 & 18 \\
0 & 15 \\
1 & 34\end{array}$ \\
\hline
\end{tabular}

*Significantly different from control, $P<005$.

TABLE $\mathrm{V}$

SCORING FOR UTERINE TONE

\begin{tabular}{|c|c|c|c|c|c|c|}
\hline & \multicolumn{2}{|c|}{$\begin{array}{c}\text { Nitrous oxide }+ \\
\text { Fluothane } \\
\text { Nov } 1959-\text { Feb } 1959\end{array}$} & \multicolumn{2}{|c|}{$\begin{array}{c}\text { Nitrous oxide }+ \\
\text { Fluothane } \\
1958\end{array}$} & \multicolumn{2}{|c|}{$\begin{array}{c}\text { All other aniaesthetics } \\
1958 \\
\text { (Control) }\end{array}$} \\
\hline & No & $\%$ & No & $=\%$ & No & $\%$ \\
\hline $\begin{array}{c}1 \\
2 \\
3 \\
\text { Total }\end{array}$ & $\begin{array}{r}1,447 \\
130 \\
24 \\
1,601\end{array}$ & $\begin{array}{rr}90 & 38^{*} \\
8 & 12 \dagger \\
1 & 50^{*}\end{array}$ & $\begin{array}{r}519 \\
39 \\
8 \\
566\end{array}$ & $\begin{array}{rl}91 & 70 \\
6 & 89 \dagger \\
1 & 41\end{array}$ & $\begin{array}{r}1,870 \\
58 \\
19 \\
1,947\end{array}$ & $\begin{array}{rl}96 & 04 \\
2 & 98 \\
0 & 98\end{array}$ \\
\hline $\begin{array}{c}1 \& 2 \\
3 \\
\text { Total }\end{array}$ & $\begin{array}{r}1,577 \\
24 \\
1,601\end{array}$ & $\begin{array}{rr}98 & 50 \\
1 & 50\end{array}$ & $\begin{array}{r}558 \\
8 \\
566\end{array}$ & $\begin{array}{rr}98 & 59 \\
1 & 41\end{array}$ & $\begin{array}{r}1,928 \\
19 \\
1,947\end{array}$ & $\begin{array}{rr}99 & 02 \\
0 & 98\end{array}$ \\
\hline
\end{tabular}

*Significantly different from control, $P<005$

†Significantly different from control, $P<001$

TABLE VI

Concentrations of Fluothane in the Blood of Mothers and Babies at the Time of Delivery

\begin{tabular}{|c|c|c|c|c|}
\hline & \multirow{2}{*}{$\begin{array}{l}\text { Average concentration } \\
\text { Fluothane } \\
(\%)\end{array}$} & \multirow{2}{*}{$\begin{array}{c}\text { Time } \\
\text { (mins) }\end{array}$} & \multicolumn{2}{|c|}{$\begin{array}{l}\text { Blood Fluothane } \\
(\mathrm{mg} / 100 \mathrm{ml})\end{array}$} \\
\hline & & & Maternal & Foetal \\
\hline 1 & 20 & 6 & 40 & 0 \\
\hline 2 & 15 & 9 & 36 & 28 \\
\hline 3 & 20 & 9 & 105 & 42 \\
\hline 4 & 20 & 5 & 57 & 22 \\
\hline 5 & 20 & 5 & 60 & - \\
\hline 6 & 07 & 17 & 34 & - \\
\hline 7 & 30 & 2 & 78 & 56 \\
\hline 8 & 15 & 3 & 80 & 42 \\
\hline 9 & 15 & 7 & 90 & - \\
\hline
\end{tabular}

Table $\mathrm{V}$ shows the ratings for uterine tone when Fluothane was used for anaesthesia: the first part showing the whole series, the second part the series for 1958, and the third part, as a control group, the ratings given with all other types of anaesthetios. A comparison of the whole series of 1,601 patients and the control group shows that more were scored as 2 and 3 in the Fluothane group. 
(Significance by chi-square, ratung 2-1 per cent level, rating 3-5 per cent level). When the ratings for 1958 are compared to the control gı oup the same differences exist although statistically the difference in rating 2 only is significant (chisquare, 5 per cent level).

Blood concentrations of Fluothane in the mother and child at the time of delivery together with the average concentration of Fluothane administered and the duration of Fluothane anaesthesia are shown in Table VI.

\section{Complications}

In this series two patients aspirated some stomach contents when Fluothane was being given and two when trichlorethylene was the anaesthetic. None of these patients had serıous sequelae There were no maternal deaths in the series. In this unit there have been no maternal deaths attributable to anaesthesia since 1946.

\section{Discussion}

In setting up this survey in 1956 it was realized that the Apgar (1953) rating for the evaluation of the condition of the newborn approached the ideal. This scoring we believed could not be carried out by the anaesthetist alone with consistent accuracy so that the simpler system was adopted. It appears to afford adequate assessment of the condition of the newborn. The question which we hoped to answer was whether babies born of mothers who are anaesthetized with Fluothane, nitrous oxıde, and oxygen are more or less depressed than when other anaesthetics are used. There is a probably significant increase in the number of babies born with a B rating in the whole group of Fluothane anaesthetics. However, the figures for 1958 show no significant differences in any of the ratungs

The part played by general anaesthesia, given to the mother, in depression of the newborn merits some discussion. Many factors are of importance in causing foetal depression and can be classified into maternal and foetal factors, the complications of labour and delivery, and the administration of analgesic drugs. In the absence of any adverse factors, general anaesthesia appears to exert little influence. Smith and Barker (6) showed that in ether anaesthesia no demonstrable depression due to ether exists un 1 l the concentration of ether in the umbilical venous blood reached $793 \mathrm{mg} . / 1 \mathrm{CO} \mathrm{ml}$ This concentration would produce surgical anaesthesia. Moreover, they found that resuscitation was required only when the concentration of ether reached $1028 \mathrm{mg} / 100 \mathrm{ml}$. blood. Apgar et al. (7) showed that there was no correlation between the concentration of cyclopropane in the foetal blood and the scores of the infant. The figures of Table VI show that when Fluothane was administered in the described fashion an insignificant quantity was to be found in the blood of the umbilical vein. The concentration which produces respiratory depression in the adult $(15 \mathrm{mg} . / 100$ $\mathrm{ml}$. blood (1)) is quite unlikely to be approached in the baby or in the mother. If deep anaesthesia were to be given to the mother, there is no question that respiratory depression would occur even in an otherwise normal baby. In the earlier part of this series, the tendency was to give deeper anaesthesia and this 
probably accounts for the slightly higher incidence of babies scored B in the whole series when compared to the control group. It is of interest to compare the figure of 87.12 per cent for A babies with the strictly comparable figure of 70 per cent for babies scored 8,9 , and 10 , that is, those in excellent cordition, given by Apgar et al. (8). This would indicate that some statistical jas is operative in Dr. Apgar's series, such as general anaesthesia which was deeper or more prolonged, or that heavier sedation was given to the mother. As in all clinical series, statistical bias cannot be considered to be absent from the series shown in Table I, however, we can conclude that with nitrous oxide, oxygen, and Fluothane anaesthesia, no undue respiratory depression of the newborn need be produced.

The over-all reduction in uterine tone after the second stage of labour with the anaesthetic Fluothane requires some comment. This findling is very much in agreement with that of Embrey et al. (2) who found that uterine contractions ceased as soon as consciousness was lost when Fluothane was administered. If this uterine relaxation were allowed to persist into the third stage of labour, postpartum haemorrhage would be more likely to occur. The figures at the bottom of Table $\mathrm{V}$ show that the incidence of post-partum haemorrhage is not significantly greater in the Fluothane group when compared to the control group (cbtained by summing ratings 1 and 2-no post-partum haemorrhage, and compariag with rating 3-post-partum haemorrhage). The important factor in technique appears to be to mantain very light anaesthesia during the third stage of labour. It is necessary to make the comment that the figures for post-partum haemorrhage shown in the hospital report list 162 for 1956, 128 for 1957, and 102 for 1958 These figures are based upon the loss of over $500 \mathrm{cc}$. blood occurring within 24 hours after delivery and from any site such as cervix, pelvic floor, or uterus, whereas the anaesthetic departmental figures include those only to uterine haemorrhage during the time of the anaesthetist's attendance in the case-room. The controls, however, were assessed in a similar fashion. It is impossible to assess the influence of Fluothane on the over-all figures, but during the years in which Fluothane has been used there has been no rise in the incrdence

We must try to explain why Fluothane is now used by the majority of anaesthetssts in the group, in spite of the risk of producisu poor uterine contraction in the third stage of labour.

Nitrous oxice, oxygen and trichlorethlyene, and cyclopropane with oxygen are the other most commonly used inhalational anaesthetics in the obstetrical unit so that we are able to make some direct comparisons, with these. Fluothane, when used with nitrous oxide and oxygen, allows a very rapid induction of anaesthesia to a sufficient depth to allow the forceps to be applied. If relaxation is required during the course of delivery, this can be produced within a few breaths. There is a strikung absence of reflex movement with manipulation when the patient is in very light anaesthesia. This type of movement is most typically seen with trichlorethylene where prevention is often beyond the potency of the agent. Some stridor may occur with manipulation, but laryngospasm has not been noted. This is in direct contrast to cyclopropane anaesthesia in which severe laryngospasm frequently occurs if manipulation is attempted before 
surgical anaesthesia has been acheved. There is no stimulation of salivary or bronchial secretions and emergence vomiting is so reliably absent that it is possible to vary the depth of anaesthesia from that necessary for forceps delivery or intra-uterine manipulation to the return of consciousness so that one might attend to the infant if required. It is very doubtful if full surgical anaesthesia with Fluothane is produced in the majority of patients and it appears to be a stage of full analgesia and amnesia from which the patients emerge without vomiting; in which they have reflex protection agaunst regurgitated material, and which allows most of the manipulations of obstetrics. The closest parallel we can offer to this state is that achieved in anaesthesia for general surgery with nitrous oxide, oxygen, and meperıdıne supplementation. If it were not for this respiratory depression occurring, with large doses of mepesidine, thıs would be almost the ideal anaesthetic com jination for delivery.

To conclude, Fluothane with nitrous oxide and oxygen forms a very controllable anaesthetic for obstetrical delivery. It should be used in the lowest possible concentration for the shortest possible time Full surgycal anaesthesia with it will produce marked uterme relaxation.

\section{SUMMARY}

Between 1956 and 1959, in the Royal Victoria Hospital, Montreal, 1,601 vaginal deliveries have been managed with nitrous oxide, oxygen, and Fluothane anaesthesia.

An attempt has been made to assess the condition of the babies and the uterine tone of mothers receiving this anaesthetic in comparison with a control group. The results show that provided that anaesthesia is maintained in a very light plane, no undue depression of respiration in the ba sies or of uterine tone in the mothers need be expected.

The place of Fluothane in obstetrical anaesthesia has been discussed.

\section{ACKNOWLEDGMENTS}

A generous supply of Fluothane was made available for this study by Ayerst, McKenna and Harrison Limited of Montreal, Canada.

We wish to thank Dr. Deirdre M. Gillies for the estimation of Fluothane in the blood and Dr. Ming Cheng for her help in the collection of the data.

\section{RÉSUMÉ}

Les tables IV, V et VI nous montrent les résultats de l'adjonction de Fluothane au protoxide d'azote et oxygène au cours de l'anesthésie en obstétrique pour l'accouchement vaginal. Ces tables permettent de faire une camparaison concernant les bébés et le tonus utérin entre le Fluothane et tous les autres anesthésiques donnés comme témoins.

Nous avons partagé les bébés en quatre groupes: 
A. L'enfant respure et crie en deçà d'une minute et contınue à ce faire tout comme un enfant normal devrait le faire

B. Un bon état mais non excellent, en deçà de 5 minutes, il récupère assez pour entrer dans le groupe $A$

C. Etat passable à mauvass avec une légère anoxie, ll court a srès son souffle et sa peau est b_eutée, ll répond aux traitements de resuscitation act.ve au point que, en deçà de 30 minutes, ll est en bon état

D. L'état est alarmant avec anoxie sévère et collapsus, il n'y a pas de respiration spontanée, la peau est pâle et moite, une atonıe musculaire exıste, le cœur bat farblement et irrégulièrement, $\mathrm{l}$ ne répond que lentement à une resuscitation active et, après 30 minutes, on ne peut pas encore dure que l'état est bon

E. Mort-né

Nous n'avons pas réussı à identıfier l'auteur de cette classificatıon. Le groupe $\mathrm{A}$ équivaut d'assez près à la classification d'Apgar 8,9 et 10 . Le groupe $\mathrm{B}$ aux classes 5,6 et 7 et le groupe $\mathrm{C}$ aux 3 et 4 Le groupe $\mathrm{D}$ équivaut aux classes $\mathrm{O}, \mathrm{I}$ et 2 .

Le tonus utérin a été apprécié et partagé en trois groupes: (1) tonus utérin normal dans le troisième stage, (ii) tout autre que le groupe 1 et 3 , (iii) hémorragie post-partum réelle (perte d'au-delà de $500 \mathrm{cc}$. de sang)

Même au risque de produire une mauvaise contraction utérine au cours du tro1sième stage de l'accouchement, nous allons essayer d'exphquer ppurquoi la plupart des anesthésistes du groupe emploient le Fluothane.

Le protoxide d'azote, oxygène et le trichForethylène, et le cyclopropane avec oxygène sont les anesthésiques par inhalation le plus fréquemment employés dans notre unité obstétricale de sorte qu'il devient facile de faîre une comparaison avec ces procédés. Lorsque le Fluothane est employé avec le protoxide d'azote et l'oxygène, l'induction est très rapide et une telle profondeur d'anesthésie est atteinte qu'il serait possible d'appliquer un forceps. $\mathrm{Si}$, au cours de l'accouchement, on a besoin de relâchement muscularre, on peut l'obtenır en quelques respiratıons. C'est étonnant comme il existe peu de mouvements réflexes à la suite des manipulations même si la malade est sous anesthésie très légère $\mathrm{Ce}$ genre de mouvements est typique au cours de l'anesthésie au trichlorethylène qui s'avère impuissant à les prévenır. Au cours des manipulatıons, il arrive d'observer du strıdor, mais nous n'avons pas été témouns des larynģ,ospasmes. Cela fait contraste avec l'anesthésie au cyclopropane au cours de -aquelle il survient souvent des laryngospasmes importants sı l'on tente de faire des manipulations avant d'avoir atteint un plan d'anesthésie chirurgıcale. Nous n'observons pas d'augmentatıon des sécrétions salıvaires ou bronchiques et il existe si peu de menaces de vomissements que l'on peut varier la profondeur de l'anesthésie du plan requis pour un forceps ou une manipulation intra-utérine au retour à la conscience ce qui permet, s'il est nécessaure, de prodiguer des soins à l'enfant. Chez la plupart des malades, nous nous demandons si nous produisons une anesthésie chururgicale complète avec le Fluothane, toutefors nous atteignons un plan d'analgésie et d'amnésie complètes d'où les malades sortent sans vomir, dans lequiel ils gardent des réflexes protecteurs contre les régurgitations et qui permet la plupart des manipulations en obstétrique. Lá parallèle le plus rapproché possible avec cet état est l'anesthésie au protoxide d'azote et oxygène 
complétée avec de la mépéridine au cours de lanesthésie chirurgicale. Si l'on pouvait éviter la dépression respiratoire qui survient avec de grosses doses de mépéridine, cela serait presque l'association idéale pour l'anesthésie obstétricale.

En somme, la Fluothane et le protoxide d'azote et l'oxygène forme un mélange anesthésique facile à contrôler pour les accouchements. Il est jréférable de l'employer aux plus faibles concentrations possibles et pour le mons longtemps possible. Une anesthésie chirurgicale complète avec ce mélange va produire une atonie utérine marquée.

\section{REFERENCES}

1. Robson, J G, \& Sheridan, C A Preliminary Investigation with Fluothane. Anesth. \& Analg 36. 62-72 (1957)

2 Embrey, M P., Garrett, W. J , \& Pryer, D L The Inhibitory Action of Halothane on the Contractility of the Human Pregnant Uterus. Lancet in 1093-1094 (1958).

3. Albert, C., Anderson, G, Wallace, W., Henleyy, E E., Winshel, A. W , \& Albert, S. N. Fluothane for Obstetrical Anaesthesia. J. Obst. \& Gynae. 13. 282-284 (1959).

4 Dixon, G D., \& Matheson, D I Fluothane and Other Non-explosive Halogenated Hydrocarbons in Clinical Anaesthesia. Canad. M A. 79 365-370 (1958).

5. Robson, J. G., \& WeLt, P The Estimation of Fluothare in Blood. Canad. Anaesth Soc. J. 4: $385-393$ (1957).

6 Smrth, C. A., \& Barker, R H Ether in the Blood of the Newborn Infant. A Quantitative Study. Am J. Obst. Gynae 43. 763-774 (1942).

7. Apgar, V., Duncan, A H, James, L. S, Prince, C E, W/eisbhot, I M., \& Weis, I Companson of Regional and General Anaesthesia in Obsteitrics with Special Reference to Transmission of Cyclopropane across the Placenta. J.A.M A. 165. 2155-2160 (1957).

8. Apgar, V.; Holaday, D. A , James, L S , Weisbrot, I. M , \& Berrien, C. The Evaluation of the Newborn Infant Second Report. J.A M A. 168. 1985-1988 (1958). 